\title{
Manufacture, Applications, and Opportunities of Thin Film Palladium-Silver (PdAg) Alloys: A Review
}

\author{
Alistair F. Holdsworth a* \\ a) School of Chemistry, University of Manchester, Oxford Road, Manchester, United Kingdom, M13 9PL. \\ * Correspondence: aliholdsworth@hotmail.com or Alistair.Holdsworth@manchester.ac.uk
}

\begin{abstract}
The noble metals palladium and silver find use in many high performance applications, and their alloys ( $\mathrm{PdAg})$, known for more than sixty years, are industrially important, finding use in many fields including hydrogen purification and separation, numerous facets of catalysis, and in fuel cells. In recent years, interest in these materials has grown significantly, particularly in energy generating applications and due to their performance as solid-state chemical sensors for a range of small molecules. PdAg thin films can be prepared using traditional physical methods such as cold rolling, or more modern and controllable chemical or physical deposition techniques such as electrodeposition or chemical vapour deposition. Despite the wide-reaching uses of PdAg, several recent advancements in materials preparation, such as additive manufacturing, better known as 3D printing, remain unexplored for this material due to the differing chemistries of the two elements. In this review, we explore the manufacturing methods commonly employed for the preparation of PdAg thin films, the common and niche applications of these materials, and opportunities for the future development of these two aspects, with an emphasis on how preparation of thin films can utilise additive manufacturing approaches.
\end{abstract}

Keywords: review; additive manufacuring; thin films; noble metals; catalysis; conductive; hydrogen technology; sensors; fuel cells; 3-D printing

\section{Introduction}

Palladium (Pd) and silver (Ag) are highly valuable elements due to their favourable corrosion resistance, ${ }^{1-3}$ excellent conductive ${ }^{1,2}$ and catalytic properties, ${ }^{1,2}$ and inherent scarcity. ${ }^{2}$ Palladium is further prized for its unique ability to chemically interact with and store hydrogen.4-6 Alloys of the two metals (PdAg) have been known for more than sixty years, ${ }^{4}$ and were first demonstrated in the 1950s and 60s by the Johnson Matthey company, who exploited their ability to purify hydrogen.6-9

Alloys of PdAg display physical, chemical and electrical properties distinct from either of the two bulk elements.,9-11 This allows for tuning of catalytic behaviour, electrical properties, or permittivity by changing the $\mathrm{Pd}$ to $\mathrm{Ag}$ ratio.6,9,12-14 Thin films of PdAg have been used for a range of applications since their discovery, ${ }^{4}$ due primarily to the characteristic properties of palladium: hydrogen permittivity and catalytic activity. ${ }^{4,9,14}$ Alloying Pd with $\mathrm{Ag}$ helps to offset some of the challenges encountered when using $\mathrm{Pd}$ in the presence of $\mathrm{H}_{2}$, discussed in detail later.5,8

Advancements in manufacturing techniques and technology generally have broadened the viable uses of $\mathrm{PdAg}$ beyond the initial hydrogen purification and catalytic applications and into fields such as sensing ${ }^{15}$ and the generation of energy in fuel cells. ${ }^{16,17}$ Though advancements in materials production developed since the discovery of PdAg have been utilised in the preparation of their films, cutting edge manufacturing techniques such as additive manufacturing have yet to be exploited, due to the difficulties in forming fully alloyed materials under typical process conditions. ${ }^{18,19}$

In this review, we explore the recent developments in the preparation and applications of $\mathrm{Pd}-$ Ag alloy thin films and highlight future opportunities for potential preparative methods, including additive manufacturing.

\section{Properties of Pd-Ag Alloys}




\subsection{Physiochemical and Mechanical Properties}

The physiochemical properties of PdAg alloys are distinct from both elements. The variation of key properties significant to a number of applications is discussed.

The enthalpies of formation $\left(\Delta \mathrm{H}_{\mathrm{f}}\right)$ of $\mathrm{Pd}_{1-\mathrm{x}} \mathrm{Ag}_{\mathrm{x}}$ alloys are marginally exothermic for all compositions, reaching peak stability at $\mathrm{x}=0.4$, where $\Delta \mathrm{H}_{\mathrm{f}}=-5.2 \mathrm{~kJ} / \mathrm{mol} .{ }^{10,20} \mathrm{Pd}$ and $\mathrm{Ag}$ both crystallise in the face-centred cubic (fcc) lattice with lattice constants of 389.07 and 405.83 Á respectively. ${ }^{20-22}$ The infinite miscibility of the two elements means that the expansion of the Pd lattice as Ag is doped into the structure is linear. ${ }^{20-22}$ The resistivity and thus electrical conductivity of Pd-Ag alloys, vary extensively with both temperature and composition. ${ }^{13}$ The room temperature variation with alloy composition is outlined in Figure 1.13

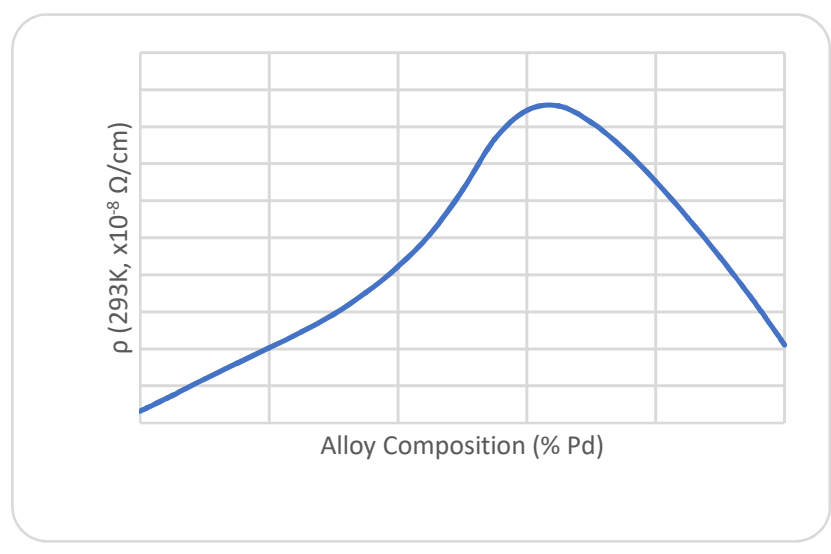

Figure 1. Variation in resistivity (Q) for Pd-Ag alloys at $298 \mathrm{~K} \cdot{ }^{13}$

The bulk resistivity of $\mathrm{Pd}$ is five times than that of $\mathrm{Ag} .{ }^{13} \mathrm{PdAg}$ alloys with $\mathrm{x}<0.8$ all have higher resistivity than elemental $\mathrm{Pd}$, up to 20 times that of elemental $\mathrm{Ag}$ at $\mathrm{x}=0.35 .{ }^{13}$ This is due to an increase in short-range ordering as the crystal lattice of Pd-Ag alloys expands with increasing Ag content, ${ }^{20}$ with contributions from energetic factors between the $\mathrm{Pd}$ and $\mathrm{Ag}$ d-orbitals increasing resistivity. ${ }^{20,13}$ The changes in these orbital energies across the Pd-Ag series can be used to tune catalytic behaviour. ${ }^{13,24}$ The conductivity of thin films is naturally lower than the equivalent bulk material, though low resistivity can be achieved through appropriate engineering of thin-film alloys.9,25,26 The magnetic susceptibility of Pd-Ag adopts the behaviour of the major component in the system: $\mathrm{Pd}$ is paramagnetic, and Ag is diamagnetic. ${ }^{11,20,27} \mathrm{PdAg}$ alloys are thus paramagnetic when $\mathrm{x}<0.5 .11,20,27$

The mechanical properties of PdAg alloys vary significantly with composition. The strength and hardness relative to elemental Pd is doubled for a PdAg alloy of $x=0.25,{ }^{4,14}$ though beyond this, the hardness of the alloys reduce with increasing Ag content.1,14 Mechanical properties are of great importance when considering the strength of gas-permeable membranes, catalysts, or electrodes, though many such systems are supported on either metallic or ceramic substrates. ${ }^{14,28}$

\subsection{Hydrogen Absorption and Permittivity}

The primary applications of metallic Pd, and by extension PdAg alloys, stem from the unique chemistry of $\mathrm{Pd}$ with $\mathrm{H}_{2}$. First demonstrated 150 years ago by Graham et al, ${ }^{29} \mathrm{Pd}$ selectively absorbs $\mathrm{H}_{2}$ to produce the variable stoichiometry compound palladium hydride, (Equation 1).5,8,30 This reversible process occurs through surface absorption, cleavage of the $\mathrm{H}-\mathrm{H}$ bond and diffusion of $\mathrm{H}^{+}$ and $\mathrm{e}^{-}$into the $\mathrm{Pd}$ crystal lattice, where the $\mathrm{H}^{+}$ions, effectively act as a metal, occupying the octahedral holes in the crystal structure. $5,8,30$ This initially results in expansion of the normal $(\alpha)$ crystal lattice, with formation of a secondary $(\beta)$ phase from $\mathrm{PdH}_{0.02}$. The $\alpha$ phase is completely converted to the $\beta$ phase by $\mathrm{PdH} 0.58 .5,30$

$$
\mathrm{Pd}+0.5 . \mathrm{nH}_{2} \leftarrow \rightarrow \mathrm{PdH}_{\mathrm{n}} \quad \text { where } \mathrm{n} \leq 1 .
$$

This property has led to the significant use of $\mathrm{Pd}$ alloys and membranes in hydrogen purification and storage. Repeated expansion and contraction of the Pd crystal lattice from adsorption and 
desorption of hydrogen results in embrittlement of pure Pd over time, however. This leads to crack formation, reduced performance and ultimately mechanical failure of the membrane in the worst case. $5,8,9,14,30,31$ Alloying Pd with Ag prevents this embrittlement, as formation of the $\beta$ phase is inhibited. This is at the expense of some hydrogen permittivity in membranes, 5,6,31,32 though the mechanical properties of the membrane are improved with higher Ag content so thinner membranes are possible as a result. ${ }^{14,32}$ Certain species such as $\mathrm{CO}^{33,34}$ and $\mathrm{H}_{2} \mathrm{~S}^{14,34,35}$ poison $\mathrm{Pd}$ (and $\mathrm{PdAg}$ ) surfaces, hindering or even preventing reaction with $\mathrm{H}_{2}$, though PdAg is less susceptible to this factor when compared to pure Pd. ${ }^{14,32-35}$

\subsection{Catalysis}

$\mathrm{Pd}, \mathrm{Ag}$ and PdAg alloys are catalytically active for a wide range of reactions due to effective absorption and reversible surface reactions with a wide range of species including $\mathrm{H}_{2}, 12,14,20,36,37$ $\mathrm{CH}_{2} \mathrm{O}^{20,23} \mathrm{CH}_{4},{ }^{38}$ and $\mathrm{CO} .15,20,39,40 \mathrm{~A}$ wide range of hydrogenation, ${ }^{41}$ dehydrogenation, ${ }^{42}$ oxidation, ${ }^{20,40,43-}$ ${ }^{45}$ reduction, ${ }^{46}$ and decomposition ${ }^{20,47-51}$ reactions of many organic and some inorganic ${ }^{46,51}$ species are catalysed by PdAg. Selectivity for targeted bond scission (such as $\mathrm{C}-\mathrm{Cl}$ and $\mathrm{C}-\mathrm{Br}$ ) on PdAg surfaces have also been demonstrated. ${ }^{52}$ These catalytic reactions are heterogeneous (gas-solid or liquid-solid) in nature and many are thermally initiated, though numerous examples of PdAg alloys used for electrolysis reactions, $14,23,24,44,47,52$ and electro- $53-55$ and photocatalysis ${ }^{56}$ have also been demonstrated. Several reactions particularly suited to use in fuel cells, such as the oxygen reduction reaction (Equation 2) are effectively performed using PdAg electrodes. ${ }^{53-55}$

$$
\mathrm{O}_{2}+2 \mathrm{H}^{+}+4 \mathrm{e}^{-} \rightarrow 2 \mathrm{HO}^{-}
$$

Pure Pd catalysts are often more active than $\mathrm{PdAg}$, though changing the $\mathrm{Pd}-\mathrm{Ag}$ ratio allows for tuning of catalytic selectivity and reduction in poisoning. $14,15,20,48$

\subsection{Electronic Properties}

In electrical and electronic applications where thick films of PdAg find use, doping of Pd with Ag prevents surface oxidation of $\mathrm{Pd}$ to $\mathrm{PdO} .{ }^{57} \mathrm{Pd}$ electrodes, while favourable for their general chemical inertness, are prone to hydrogen embrittlement in the same manner as membranes of the element used in gas separation. ${ }^{58}$ As per hydrogen separation, alloying Pd electrodes with a proportion of $\mathrm{Ag}$ reduces embrittlement. ${ }^{59-61} \mathrm{H}_{2}$ permeable PdAg electrodes have been utilised as cathodes in electrolytic hydrogen production, where the Ag serves to prevent embrittlement, while retaining the electronic behaviour of elemental Pd. ${ }^{11}$ In electro-catalysis and electrolytic applications, the doping of $\mathrm{Ag}$ into Pd reduces the activity the catalyst due to the lower activity of d-band electrons within the alloy relative to pure Pd. ${ }^{20,49,62-64}$ The lower activity of the d-band electrons is a result of the filling of d-holes in the Pd electronic structure as $\mathrm{Ag}$ is doped into the crystal lattice. ${ }^{64}$

\section{Manufacture of Pd and Ag Alloy Thin Films}

Since their inception, a broad range of physical and chemical methods have been utilised to prepare $\mathrm{Pd}, \mathrm{Ag}$ and $\mathrm{PdAg}$ films. ${ }^{20}$ Certain applications may use materials prepared a single manufacturing technique, as the properties essential end use of the material are closely influenced by the preparative route. For example, $\mathrm{PdAg}$ thin films for sensor applications are commonly prepared using CVD or $\mathrm{PVD}, 36,65-73$ while those for use in gas separation may use electroless deposition ${ }^{14,22,28,31,35,74-89}$ or mechanical methods ${ }^{14,33,85,92-94}$ though this is not exclusive.

Despite the range of available preparation techniques for PdAg films, recent advancements in materials preparation, such as additive manufacturing (AM), ${ }^{93}$ better known as 3D-printing, have not been exploited, despite the versatility of the technique. Films of Ag produced by AM are well known, however, and Pd films have been similarly prepared though are less well known. 18,19,25,26,94-119 Thus the potential for preparation of PdAg using AM represents an unexplored opportunity.

To develop an understanding of how AM could be applied to the manufacture of PdAg films, the chemistry and physics of existing conventional and additive approaches must first be understood. The differing chemistries of $\mathrm{Pd}$ and $\mathrm{Ag}$ will affect the approach taken. ${ }^{120}$ Achieving a homogeneous 
film is essential to ensuring the performance of a PdAg film in the target end goal. Achieving this while avoiding the extensive heat treatment commonly required to produce homogeneity in a $\mathrm{PdAg}$ film would increase the potential variety of substrates and systems with which it could be used, ${ }^{14,83,121,122}$ such as plastics and fabrics.

With this in mind, the conventional (i.e. non-additive) manufacturing of $\mathrm{Pd}, \mathrm{Ag}$ and $\mathrm{PdAg}$ films will first be explored with reference to how choice of manufacturing method is affected by end application.

Following this, the routes by which $\mathrm{Pd}$ and Ag films have been additively manufactured are investigated, and several potential routes to the preparation of PdAg films using AM are outlined. An overview of PdAg nanoparticles preparation is also presented as these provide one of the potential routes to PdAg films using additive manufacturing. A number of researchers have performed in-depth analysis into the preparation of PdAg membranes, though these are generally focused on specific applications. ${ }^{14,22,122}$

\subsection{Conventional Manufacture}

A range of conventional manufacturing methods have been employed for the preparation of $\mathrm{Pd}$, Ag and PdAg metallic thin films. These vary from physical methods, whereby thin films are prepared by rolling of alloys; ${ }^{14}$ electrolytic methods, whereby thin films are deposited from an aqueous solution of metal salt precursors; ${ }^{28}$ physical vapour (PVD), ${ }^{75-78}$ chemical vapour (CVD), ${ }^{122}$ and atomic layer deposition (ALD), ${ }^{123-125}$ whereby the films are deposited from a metal target or decomposition of volatile precursors respectively; spray and flame pyrolysis, where a film is deposited by thermal decomposition of precursors in a high temperature flame; ${ }^{126,127}$ to screen printing ${ }^{128}$ and spin coating, ${ }^{129,130}$ whereby films are printed through a mask or spun onto a rotating substrate, with reactive or particulate precursors heated to form the film. These methods are discussed, with examples, by technique, with applicability to the preparation of $\mathrm{PdAg}$ films, and with examples of end use for each technique.

\subsubsection{Physical Methods}

The simplest method of metal film production is to physically prepare the film from the bulk material through either rolling or hammering. ${ }^{14,131}$ Many of the noble metals are ductile and malleable, allowing them to be readily processed into thin films using such methods. ${ }^{1} \mathrm{PdAg}$ films produced via this method are prepared from $\mathrm{Pd}$ and Ag metals which are melted and sintered together to achieve a homogenous bulk phase. This bulk material is then normally cold-rolled to make the films of the desired thickness. ${ }^{14,49,81,83,90-92}$

Mechanical methods such as cold rolling lack the manufacturing consistency and control of chemical techniques such electroless plating and CVD, and introduce stresses in the material which must be removed by heat treating. ${ }^{132}$ They are however advantageous in their simplicity and scalability. Mechanical methods have been used extensively to prepare PdAg films for gas-selective membranes, ${ }^{14,49,81,83,90-92}$ and was used for an early example of a $\mathrm{H}_{2}$ sensor. ${ }^{131}$

\subsubsection{Electrolytic and Electroless Methods}

One of the oldest, simplest and most prevalent methods of noble metal film preparation is electrodeposition, or electroplating. In this method, a film is deposited from a solution containing the target ion(s) by electrically reducing them onto the desired (conductive) substrate, using the substrate itself as the cathode in an electrochemical cell. ${ }^{133}$ An overview of this is presented in Figure 2. 


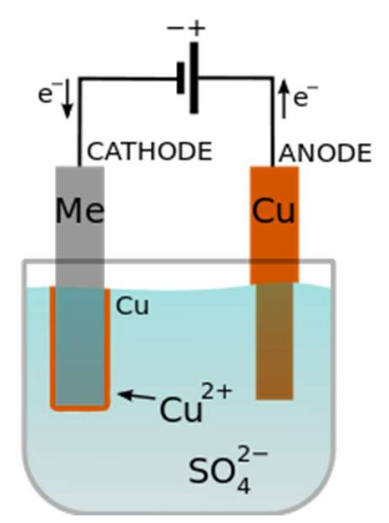

Figure 2. Schematic of electroplating (Open source image: Wikipedia).

A development of electrolytic plating is electroless plating. A solution containing the target ion(s) to be deposited is contacted with the substrate and a separate reducing agent is added. This mimics the electrical current in electrolytic plating to effect the deposition of the ions on the substrate surface. ${ }^{134}$ In this case the substrate serves to nucleate the plating of the target ions. ${ }^{134}$ Electroless plating is advantageous in that non-conductive substrates such as ceramics can be used. ${ }^{134}$

Electroless plating has been extensively used to prepare thin films of PdAg, especially for use in hydrogen purification and catalytic applications. ${ }^{14,22,28,31,35,74-89}$ Common precursors are commercially available and include complexed $\mathrm{Pd}^{2+}$ and $\mathrm{Ag}^{+}$salts reduced with reducing agents such as tin (II) salts, formate ions, or hydrazine. ${ }^{31,53}$ The main advantage of electroplating and electroless deposition methods are their simplicity, but conversely control over the deposited films is lower than other methods. ${ }^{32,81,135}$ Extensive post-precipitation heat treatments can also be required to achieve homogenous alloys and the desired level of conductivity of catalytic activity in films prepared via these preparative routes, however, due to the different electrochemistry of $\mathrm{Pd}$ and $\mathrm{Ag}$ causing different rates of deposition. ${ }^{122}$ Mechanisms of electroless deposition and surface morphologies such $\mathrm{PdAg}$ films have been investigated extensively. ${ }^{14,87-89}$

\subsubsection{Physical Vapour, Chemical Vapour and Atomic Layer Deposition}

Vapour Layer deposition techniques deposit materials on a target surface by a range of related methods. Physical vapour deposition for example, (PVD, Figure 3) utilises high energy ions (such as $\mathrm{Ar}^{+}$) in the form of a plasma to "knock" ions from a bulk target onto the desired substrate. ${ }^{136}$ The process is conducted under vacuum and an electrical potential is often employed between the target and the substrate to aid the process, though thermally the process is conducted under ambient temperature, and is also referred to as "sputtering". ${ }^{137}$ PVD can also be used for the preparation of coarser thin films than can be achieved with chemical vapour or atomic layer deposition methods outlined below, as the deposition rate is up to two orders of magnitude higher. ${ }^{65}$ Several researchers have demonstrated the sputtering of PdAg alloys using separate targets of Pd and Ag. ${ }^{14,32,75-78} \mathrm{PVD}$ methods are used extensively to prepare PdAg films for sensor applications, ${ }^{65-73}$ and to a lesser extent, for gas-permeable membranes. ${ }^{81,135}$
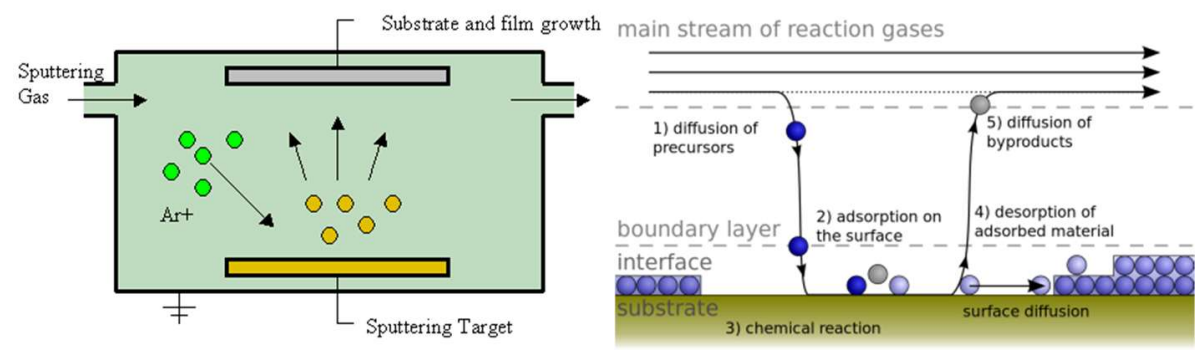

Figure 3. Schematics (Left to right) of PVD, and CVD. (Open source images: Wikipedia). 
Chemical vapour deposition (CVD, Figure 3) uses thermally labile precursors which are decomposed by heat to produce thin films of metals, oxides or other compounds on a substrate.138 This is often performed under vacuum and at elevated temperatures, thus limiting the available substrates that can be utilised. PdAg films have been prepared using this method using $\mathrm{Pd}$ and $\mathrm{Ag}$ acetates as the precursors, ${ }^{122}$ though other suitable species for both elements are available. ${ }^{14,26,139,140}$

Atomic layer deposition (ALD, Figure 4) is an evolution of CVD whereby tuneable layers of the desired element or compound are precisely applied to the substrate based on sequential, self-limiting decomposition reactions. ${ }^{141}$ ALD has a significantly lower deposition rate than PVD or CVD, but the control over deposition is far greater. ${ }^{65}$ While PdAg alloy films have not been prepared using ALD to our knowledge, films of both individual elements have successfully deposited. ${ }^{123-125}$
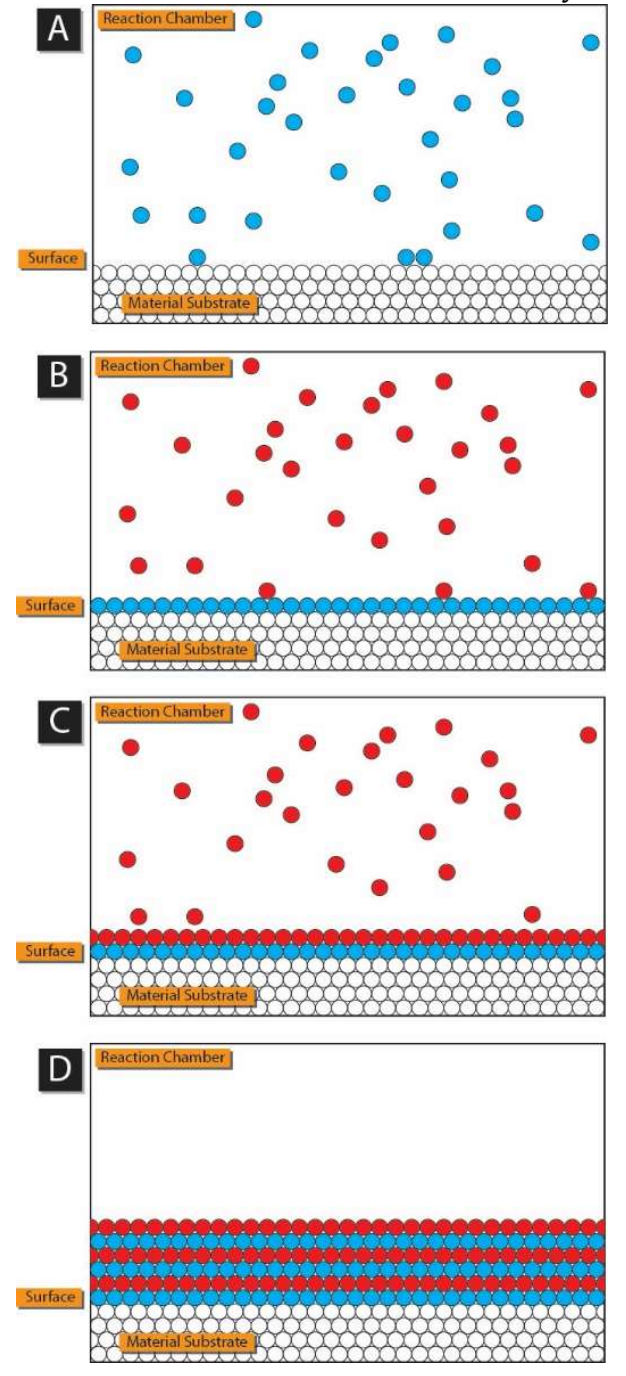

Figure 4. Schematic of ALD. (Open source image: Wikipedia).

High throughput preparation and screening methods have been applied to Pd-Ag-Ti membranes for $\mathrm{H}_{2}$ separation by Piskin et al. The samples in this research were prepared using PVD. ${ }^{142}$

Vapour deposition methods are advantageous over the other methods explored for applications where finely controlled deposition of a PdAg film is required. They are disadvantageous however in that rates of deposition are lower than electroplating, the high temperatures required can limit the viable substrates, and high capital costs are required for equipment and precursors compared to other methods. ${ }^{14}$

\subsubsection{Spray and Flame Pyrolysis}

Spray pyrolysis (Figure 5) is a technique for the preparation of thin films whereby a solution containing the desired film precursors is sprayed onto a heated surface and thermally decomposes 
to form the intended film. ${ }^{143}$ With careful control over process parameters, thin films of $500 \mathrm{~nm}$ thickness can be prepared. ${ }^{144}$ Flame pyrolysis is a related technique whereby the desired film is deposited from a gaseous combustion ${ }^{126}$ or plasma ${ }^{127}$ flame.

Li et al demonstrated the preparation of a 2 um PdAg membrane onto an alumina support from the respective metal nitrates, deposited from a $\mathrm{H}_{2}-\mathrm{O}_{2}$ flame at $1000{ }^{\circ} \mathrm{C} .{ }^{126}$ Precursors to PdAg films in the form of spherical particles have also been prepared using flame pyrolysis, ${ }^{144}$ and fully alloyed PdAg particles can be prepared using spray pyrolysis in a single step. ${ }^{145}$

\subsubsection{PdAg Nanoparticle Preparation}

$\mathrm{Pd}^{146-148} \mathrm{Ag}^{148-156}$ and PdAg157-161 nanoparticles have been known for many years and find use in a wide range of applications in their own right, but these uses are beyond the scope of this review and as such are not discussed further. Such particles also find use as precursors to PdAg films, ${ }^{109,113}$ and as such an overview of their preparation is presented.

Noble metal nanoparticles are most commonly prepared using solution reduction of metal salts using an appropriate reducing agent. ${ }^{158}$ These reactions are generally conducted in dilute batch reactions and as such throughput is limited, 158 though advances of nanomaterials manufacturing into the continuous mode improve throughput, are scalable and more consistent than batch methods. ${ }^{148,151}$ Due to their high surface energies, ${ }^{162}$ metal nanoparticles often require capping to prevent agglomeration. ${ }^{147,148,158}$ Flow processes allow for efficient capping of nanoparticles in process. ${ }^{148,151}$

Monometallic nanoparticles require less consideration of synthesis than bimetallic examples (such as PdAg). Ag@Pd core-shell nanoparticles capped with PVP were prepared by Tedsree et al.161 This preparation involved synthesis of an $\mathrm{Ag}$ core then several subsequent reductions of Pd onto the surface until the desired composition was reached. ${ }^{161}$ Co deposition without the requirement for a core-shell approach to bimetallic nanoparticles can be conducted using rapid reduction with a powerful reducing agent such as $\mathrm{NaBH}_{4}, 159,160$ though this technique does not fully alloy the metals into a homogenous phase. ${ }^{159}$

Noble metal nanoparticles can also be prepared at scale using the spray or flame pyrolysis method, ${ }^{163}$ though this lacks the finer control of particle size and morphology inherent to solution based methods..$^{148}$

Free powdered or stable suspensions of nanoparticles are ideal precursors to several different additive manufacturing techniques, which shall be discussed later.

\subsubsection{Screen Printing}

Conductive films of PdAg have been prepared using screen printing (Figure 5) for many years from either reactive solution or (nano)particulate-based precursors. $128,164-170$ In this method, the conductive precursor is applied to the substrate through a porous screen topped with a negative "mask" of the design to be printed. The conductive film is then developed either photochemically or thermally to decompose or sinter the precursors as required. ${ }^{171}$ This is often conducted at high temperatures $\left(>200^{\circ} \mathrm{C}\right)$, limiting the substrates which can be used..$^{144}$

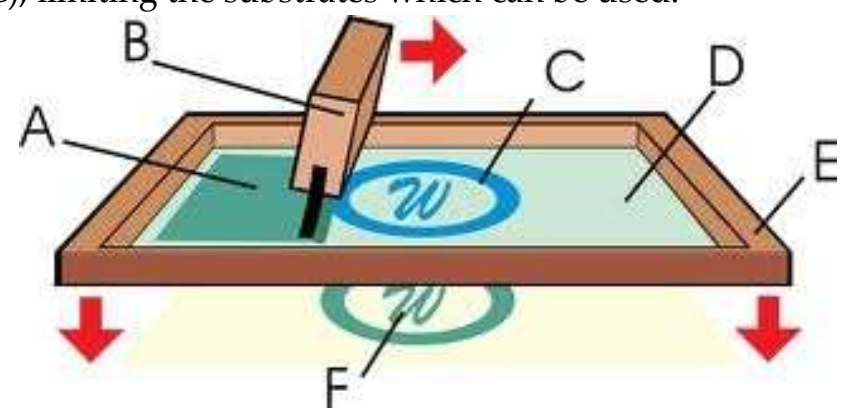

Figure 5. Schematic of screen printing. A: ink; B: squeegee, C: image negative; D and E: screen and frame; F: printed image. (Open source image: Wikipedia). 
A range of commercial reactive and nanoparticulate inks are available for this printing of $\mathrm{PdAg}$ films, though these are hindered by the aforementioned requirement for high sintering temperatures. ${ }^{144,170}$ The resolution and minimum thickness of the printed film are also limited due to the nature of the screen printing process itself with respect to precursors concentration and mask pore dimensions. ${ }^{144,164,170}$

\subsubsection{Spin Coating}

Spin coating (Figure 6) is a technique for application of thin films to a substrate, whereby a liquid film is applied as a suspension or solution to a spinning disk of the substrate, followed by in-process or subsequent evaporation of the carrier solvent. The thickness of the film can be controlled by variation of rotation rate, viscosity of the ink and the concentration of the printed component. ${ }^{172}$

Spin coating is ideal where sequential layers of different materials need to be deposited, such as microelectronics. ${ }^{173}$ If drying is conducted during the spinning process, care must be taken to avoid the "coffee-ring" effect, caused by variations in the viscosity of the ink during the process. ${ }^{174}$

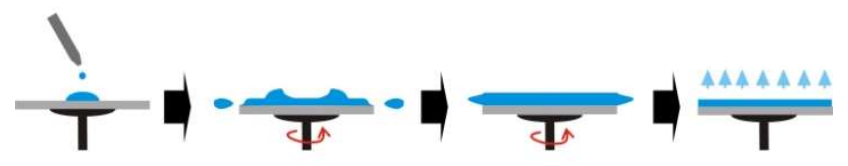

Figure 6. Schematic of spin coating in 4 stages: deposition, progressive spinning, film formation, and drying. (Open source image: Wikipedia).

Screen printed metallic films, can use either be reactive or particulate precursors. As per screenprinted samples, however, both of these often require post-spin thermal or other treatment in order to prepare the desired conductive film. While no researchers have demonstrated the spin-coating of PdAg films, films of both $\mathrm{Pd}^{129,175}$ and $\mathrm{Ag}^{130,176}$ have been deposited individually. Similar precursors to those used in screen printing could be used to print PdAg films via spin coating.

\subsection{Additive Manufacturing}

Additive manufacturing (AM, Figure 7), formerly known as rapid prototyping and more colloquially known as "3D printing" is a state-of-the-art manufacturing technique whereby layers of a material are deposited sequentially under computer control to construct a 3D shape..$^{93}$ This covers a wide range of techniques encompassing fused deposition modelling (FDM), ${ }^{177}$ selective laser melting (SLM), ${ }^{178}$ inkjet printing ${ }^{94,95}$ and binder jetting. ${ }^{179}$ Rapid prototyping conceptually began to gain momentum in the published literature in the early 2000s, with the terms additive manufacturing and 3D-printing overtaking the progenitor in 2013.93 The volume of research concerning these concepts has increased year on year since then.

AM can be used to prepare objects of almost any conceivable shape from a vast range of materials including plastics, ceramics, and metals. ${ }^{180}$ Some techniques under the umbrella of AM are more suited to some materials and end applications than others by nature of the diversity of the field. $.3,180$

Conductive metal films, including those of elemental Pd and Ag, have been prepared using AM techniques, but most commonly inkjet printing, for over 30 years. ${ }^{179}$ These are well documented for a variety of applications, such conductive traces, sensor electrodes and catalysts when prepared on a variety of substrates including glass, plastics and even fabrics. ${ }^{18,19,94-119}$ These are most commonly deposited from reactive solutions ${ }^{25,26,94-98,101,103,105,111,114-116}$ or nanoparticulate suspensions ${ }^{18,19,102,104-}$ 110,112,113,117,118 using inkjet printing, though some researchers have taken a hybrid route. ${ }^{99}$ 


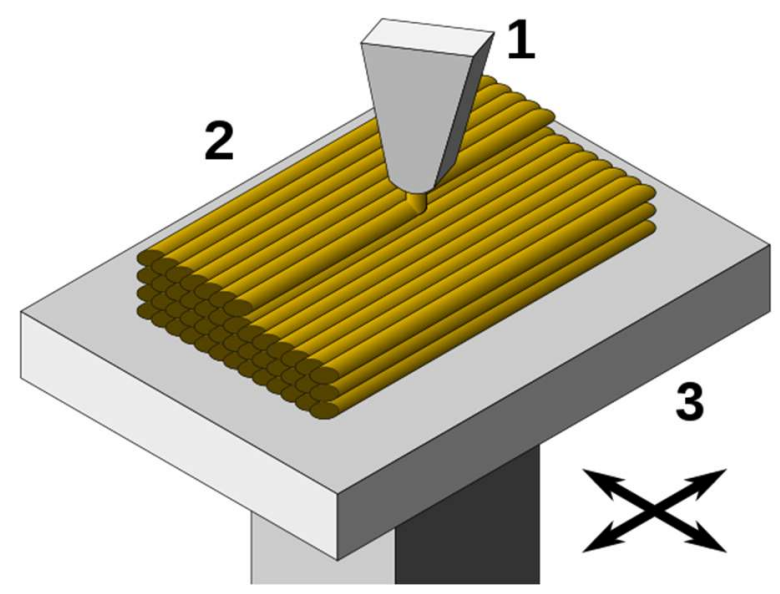

Figure 7. Overview of fused-deposition modelling: 1: print extruder; 2: deposited material; 3: 3-D movable table. Plastic strands are deposited layer-by-layer to produce the desired 3-dimensional object. (Open source image: Wikipedia).

The potential for printing of PdAg films using inkjet printing will be discussed in detail. Such films have not been prepared using any AM technique, representing an unexplored opportunity within the field. Inkjet printing using reactive or particulate liquid precursors is ideal for preparation of metallic films as the product properties are readily controlled during the manufacturing process. ${ }^{25,26,179} \mathrm{Ag}$ films have extensively been prepared using inkjet printing, ${ }^{100-124}$ and $\mathrm{Pd}^{115}$ films have also been demonstrated. ${ }^{178,179}$

Other AM techniques such as SLM ${ }^{178}$ or binder jetting ${ }^{179}$ could make use of PdAg (nano)particles to prepare complex 3D shapes with a high surface area. While these techniques are not suitable for the preparation of PdAg thin films, these methods represent the forefront of AM technology for preparation of $3 \mathrm{D}$ shapes, and could be used to prepare more porous structures suited to catalysis $^{181,182}$ or sensing ${ }^{183}$ applications. The higher surface area in these cases leads to higher activity. ${ }^{181-183}$ To our knowledge, this has never been achieved with PdAg.

\subsubsection{Additive Manufacture of PdAg using Inkjet Printing}

The two common types of ink used for the inkjet printing of conductive metallic films are either nanoparticle-based nanoparticulate ${ }^{18,19,102,104-110,112,113,117,118}$ or reactive solution-based $25,26,94-98,101,103,105,111,114-$ 116 inks. Solution based inks can be further sub-divided into organic ${ }^{26}$ or inorganic, ${ }^{25}$ depending upon the nature of their solution and decomposition chemistry.

Nanoparticulate formulations, consisting of a suspension of particles in a solvent, are advantageous in that the precise composition of the metals within the ink is predetermined.18,19 Several challenges exist in the use of such inks, however. In order to stabilise the suspension, the nanoparticles must often be capped with suitable stabilising agents. ${ }^{105,184}$ The complete removal of these capping agents requires extensive heating after or during the printing process, limiting the number of viable substrates. $106,184,185$ Similarly to achieve adequate conductivity, sufficient sintering of the particles must be performed through particle ripening, 18,19 though sintering, solvent evaporation, and capping agent removal can all be combined into a single step. As with all particulate suspensions, there is a propensity to block or clog the narrow orifices used in inkjet printing heads, though the use of capping agents can mitigate this. ${ }^{105,186}$ Several commercial inks containing Pd and Ag nanoparticles exist for screen printing applications, and similar Ag or Pd inkjet-printable formulations have been developed, $8,19,102,104-110,112,113,117,118$ but to our knowledge, both metals have never been simultaneously inkjet printed together from nanoparticulate inks.

Solution based inks exploit the known ability of many noble metal compounds to decompose under mild conditions. $26,94,95,187,188$ These types of ink can be grouped into two broad groups based on their chemistry and solvent base: organic ${ }^{26}$ and inorganic. ${ }^{25}$ Organic inks often utilise air- and watersensitive metal complexes dissolved in a suitable organic solvent, which break down at elevated 
temperatures to form the desired metal. $26,94,95,187$ These are sometimes called metal organic decomposition (MOD) inks. The decomposition chemistry of these types of reagent is often related to that of CVD precursors, though in some cases incomplete decomposition of the metal complex can leave impurities in the film. ${ }^{26}$ One notable example of this is the work of Black et al, whereby a toluene-based ink containing a silver hfac complex in conjunction with isopropyl alcohol as a coreductant forms a composition stable at room temperature, but which activates to reduce to the metal at elevated temperatures (Equation 3) This method is advantageous in that all the decomposition byproducts are volatile and the produced films are free of impurities. ${ }^{26}$

$$
2[\mathrm{Ag}(\mathrm{hfac})(\mathrm{COD})](\text { org) })+\mathrm{iPr}-\mathrm{OH}_{(\text {org })} \rightarrow 2 \mathrm{Ag}(\mathrm{s})+2 \mathrm{H}-\mathrm{hfac}_{(\mathrm{g})}+2 \mathrm{COD}_{(\mathrm{g})}+\left(\mathrm{CH}_{3}\right)_{2} \mathrm{CO}_{(\mathrm{g})} \text { (3) }
$$

Inorganic inks typically use tailored aqueous chemistry, often based on that of electroless plating, such as the work of Walker, ${ }^{25}$ which utilises a solution stable at room temperature, but which activates to reduce the contained metal complex to the metal under elevated temperatures. The aforementioned example utilises a modified Tollens' process (Equation 4), which is activated upon heating. Due to the reversal of the electrode potentials in the system at elevated $\mathrm{pH}$ and the complexation of the metal, the solution is rendered inert at room temperature. ${ }^{189,190}$ This solution is available commercially. As per the work of Black, ${ }^{26}$ all of the reaction by-products are volatile at the temperature of the reaction..$^{25}$ Thus conductive traces can be produced by simply printing the reactive ink onto a heated surface.

$$
2\left[\mathrm{Ag}\left(\mathrm{NH}_{3}\right)_{2}\right] \mathrm{OAc}(\mathrm{aq})+\mathrm{CH}_{2} \mathrm{O}_{2(\mathrm{aq})} \rightarrow 2 \mathrm{Ag}_{(\mathrm{s})}+\mathrm{CO}_{2(\mathrm{~g})}+\mathrm{HOAc}_{(\mathrm{g})}+4 \mathrm{NH}_{3}(\mathrm{~g})
$$

While combined PdAg films have not been inkjet printed simultaneously from a single component reactive ink, a range of solutions exist for both metals individually with differing degrees of processing conditions and practical viability. The challenge for this type of system would be ensuring simultaneous precipitation of both elements to eliminate the need for lengthy high temperature annealing.

\subsection{Alloying, Sintering and Oxidation}

Achieving a uniform alloy is essential to the performance of PdAg alloys and their thin films. This requires homogenous deposition of Pd and Ag or heating to alloy sufficiently for the desired conductive or catalytic behaviour to be achieved, ${ }^{99}$ though co deposition can be challenging due to the differing chemistries of the two elements.

In the case of particulate systems, the high surface energy of nanomaterials results in rapid agglomeration of unstabilised NPs to form larger species. ${ }^{191}$ Smaller particles have higher surface energies, ${ }^{99}$ best illustrated by the significant reduction in melting point with reduction in particle size below $10 \mathrm{~nm}$ for the majority of metal NPs. ${ }^{191}$ In systems where Pd and Ag are combined together in pre-alloyed particulates, the necessity for extensive heat treatment can thus be avoided beyond those necessary to anneal the particles together. ${ }^{18.19}$ In solution based systems, the different electrochemistries of $\mathrm{Pd}$ and $\mathrm{Ag}$ can mean that one metal or the other can be reduced before the other depending upon the reaction conditions used..20 Generally, higher curing temperatures result in higher conductivities from more complete alloying. This is thus a balance between the substrate, film deposition chemistry and reaction time for optimum performance. ${ }^{117,118}$

Several researchers have demonstrated that sintering can be conducted using microwaves ${ }^{18,19}$ or plasma ${ }^{106}$ instead of thermally. This can be advantageous, as surface oxidation of Pd to PdO during thermal annealing (Equation 5) can be detrimental to the final performance of the film or membrane. ${ }^{57,139}$

$$
2 \mathrm{Pd}(\mathrm{s})+\mathrm{O}_{2(\mathrm{~g})} \leftarrow \rightarrow 2 \mathrm{PdO}_{(\mathrm{s})}(5)
$$

The oxide is unstable with respect to the metal and decomposes back to elemental Pd by 900 ${ }^{\circ} \mathrm{C} .{ }^{57,192}$ Introduction of $\mathrm{Ag}$ into the $\mathrm{PdO}$ system hinders oxidation and lowers the decomposition temperature of $\mathrm{PdO} .57$

\section{Applications of PdAg Thin Films and Membranes}


The key properties of PdAg alloys are outlined above, and the scope of his review does not extend to bulk or free or supported (nano)particulate PdAg systems, so these will not be discussed further here. The vast majority of research investigating PdAg thin films can be divided into two categories: chemical separation, catalysis, and sensing. In both cases, this primarily exploits the known chemistry of $\mathrm{Pd}$ (and its alloys with $\mathrm{Ag}$ ) with $\mathrm{H}_{2}$, though this is not exclusive.

\section{1:. H2 Separation and Catalysis}

The major application of $\mathrm{PdAg}$ thin films is the separation of $\mathrm{H}_{2}$ from other gases. $4,14,20,22,28,31,33,42,51,76-92,126,135,193-207$ This known property can be combined with thermal heterogeneous catalytic activity, either from the film itself or from additional catalysts. These are generally continuous processes, ${ }^{14,22,28,33,42,81-83,202,203,205}$ as overall process efficiency compared to the batch mode is increased as selective removal of one or more species in catalytic equilibrium processes serves to drive the reaction(s). ${ }^{81} \mathrm{PdAg}$ alloys of $\mathrm{x}=0.2-0.3$ are the optimum formulation range for $\mathrm{H}_{2}$ permeable membranes, ${ }^{14,32,33,35,80,81,89-92,201,207}$ with $\mathrm{x}=0.23$ providing the highest hydrogen permittivity. ${ }^{31}$ An extensive volume of extant literature provides deep insight into the use of PdAg films in membrane reactors. ${ }^{81,196,197}$ Here, we present a brief overview.

The $\mathrm{H}_{2}$ permittivity of PdAg membranes is sensitive to a number of factors. ${ }^{14}$ Larger metallic crystallites tend to increase permittivity, ${ }^{135}$ while increased Ag content $(x=0.35)$ forms smaller crystallites, lowering permittivity. ${ }^{126}$ This size of crystallites is sensitive to production method. ${ }^{126}$ $\mathrm{PdAg}$ membranes are often supported on porous supports of either stainless steel or ceramic construction. ${ }^{14,22,28,31,74-89,199,200}$ Chemical pre-treatment of ceramic supports has been demonstrated to improve membrane-support bonding, ${ }^{126}$ though expansion during annealing can result in delamination of the membrane from the support if reactor construction (PdAg membrane internal or external of the support) is not considered. ${ }^{80}$ The effect of annealing conditions on permittivity has been extensively studied, and incomplete annealing or segregation of $\mathrm{Ag}$ and $\mathrm{Pd}$ results in reduced permittivity. ${ }^{24,208}$

PdAg films for separation or catalytic purposes are commonly prepared using mechanical methods $8,9,92,84,90-92,202,203$ or electroless deposition ${ }^{14,28,31,74-89,199-200}$ on the aforementioned porous substrates or supports, though PVD can provide greater control over film properties and has found some use in this application. ${ }^{81,135}$ Supports allow membranes to be thinner and thus more efficient and cost-effective than self-supporting ones..$^{14}$ More traditional mechanical techniques have also been employed for the preparation of such membranes.

The hydrogen flux through pure $\mathrm{Pd}$ and PdAg membranes have been investigated extensively. $79,81,199,200,203$ The hydrogen flux is inversely proportional to membrane thickness, $79,199,200,209$ proportional to a half power of both temperature, $199,200,209$ and pressure. ${ }^{91,201}$ Such processes are very sensitive to start up conditions, however, ${ }^{204}$ and hydrogen flux is limited below $200^{\circ} \mathrm{C} .{ }^{79}$ The optimum operating temperatures for $\mathrm{PdAg}$ membranes are above $300{ }^{\circ} \mathrm{C}, 79,209$ with higher temperatures increasing $\mathrm{H}_{2}$ permittivity. ${ }^{204}$ Surface oxidation can improve the $\mathrm{H}_{2}$ permeation of $\mathrm{PdAg}$ membranes by $90 \%, 91,92,199,200,206$ and reduce the deleterious effects $\mathrm{CO}$ poisonging can have on $\mathrm{H}_{2}$ permittivity. ${ }^{207,210,211} \mathrm{H}_{2} \mathrm{O}$ has been demonstrated to hinder $\mathrm{H}_{2}$ permeation through $\mathrm{PdAg}$ membranes through competitive binding, though this process is reversible and of lower effect at higher temperatures. ${ }^{202,203,207}$ Species such as $\mathrm{H}_{2} \mathrm{~S}$ can permanently poison membranes, ${ }^{84-86}$ though doping $\mathrm{PdAg}$ with a small amount of Au reduces this effect. The reduction in performance by competitive $\mathrm{CO}, \mathrm{H}_{2} \mathrm{~S}$ or $\mathrm{H}_{2} \mathrm{O}$ binding is reduced at higher temperatures. ${ }^{207}$ Higher Pd content in PdAg membranes results in higher resistance to sulphide deactivation while increasing hardness. ${ }^{1}$ The inclusion of $\mathrm{Ag}$ to Pd films doubles the effective lifespan of the membrane. ${ }^{82}$ The selectivity of a PdAg membrane for hydrogen depends upon the composition of the gaseous mixture in question, but selectivity from similarly light species such as He approaches 4 orders of magnitude. ${ }^{133}$

One of the primary applications of PdAg membranes is the separation of $\mathrm{H}_{2}$ from other gases produced from the steam reforming and water-gas shift reaction (Equations 6 and 7).32,42,75$78,81,83,202,203, .205$ 


$$
\mathrm{CO}+\mathrm{H}_{2} \mathrm{O} \leftarrow \rightarrow \mathrm{CO}_{2}+\mathrm{H}_{2} \mathrm{O}(7)
$$

These reactions are commonly conducted over a nickel or oxide catalyst at high temperatures and, ${ }^{81}$ as equilibrium processes, removal of hydrogen through the selective PdAg membrane drives the (continuous) reaction processes to the right hand side. ${ }^{205}$ The excellent review of Dittmeyer $e t$ al, ${ }^{42}$ provides good diagrammatic overviews of such processes.

Various other catalytic reactions have been explored in combination with the selective $\mathrm{H}_{2}$ permittivity of PdAg films including hydrogenations, dehydrogenations, oxidation, reduction, and decomposition processes. ${ }^{14,81,90,202,203}$ The catalyst in these processes can either be the film itself $f^{14,22,42}$ or an additional heterogeneous species. $22,32,42,83,205$ Such examples of membrane catalysis include a lowpressure methanol reforming process using a PdAg membrane $(x=0.23)$ to separate the produced $\mathrm{H}_{2} .81,90$

\subsection{Sensing}

\subsection{1. $\mathrm{H}_{2}$ Sensing}

One of the earliest applications of PdAg alloy thin films in sensing was explored by Shaver. ${ }^{131}$ This research noted a $100 \mathrm{um}$ bimetallic PdAg $(x=0.25)$ strip thermally bonded to Fe with a $\mathrm{Cu}$ separator changes conformation when exposed to $\mathrm{H}_{2}$. Since then, advancements in electronic equipment have allowed the development of solid state devices which exploit changes in the resistance of PdAg alloys when exposed to $\mathrm{H}_{2}$ to allow for detection of the gas over wide ranges (ppm to ppt). ${ }^{12,15,36,66-73,122}$ Optical sensors containing PdAg films as the active sensing component have also been explored. ${ }^{73}$ These sensors can employ a range of substrates, ${ }^{122}$ but the PdAg films are commonly deposited using PVD sputtering methods, ${ }^{12,36,66-73}$ or more rarely CVD. ${ }^{122}$ The range of PdAg alloys in these applications typically varies from $x=0.2$ to $0.3,{ }^{73}$ as this limits the hydrogen embrittlement observed with pure Pd membranes and electrodes.

\subsubsection{Other Sensing}

The capability of PdAg films to absorb species other than $\mathrm{H}_{2}$ allows for the sensing of alternate low-molecular weight compounds.15,20,40 Ghosh et al noted a $\mathrm{ZnO}$ supported PdAg film operates effectively as a sensitive, low-temperature, highly selective $\mathrm{CH}_{4}$ sensor in the presence of competing gases. 38,212 The PdAg film in this research was prepared using PVD.

\subsection{Other Applications}

Though sensing and hydrogen permittivity are the primary applications, other applications of PdAg thin films such as electrochemistry have been explored.

\subsubsection{Electrochemistry}

Pd electrodes have been utilised for many years for a wide range of electrochemical processes due to their versatile reactivity and corrosion resistance. Introduction of Ag into these electrodes can be used to tune reactivity and/or increase resistance to certain poisons within a given system. ${ }^{24,129}$

Oliveira demonstrated both alkaline ethanol oxidation and oxygen reduction reactions using $\operatorname{PdAg}(x=0.21)$ electrodes for use in fuel cells..$^{45}$ Similar electrodes have been used for methanol reduction, ${ }^{128}$ and have been prepared using screen printing from nanoparticulate PdAg inks. A combined electrolysis and separation system has been demonstrated by Pozio et al, whose research utilised a hollow PdAg membrane cathode to produce ultrapure hydrogen from an electrolysis cell. ${ }^{60}$

\subsubsection{Minor Applications}

Markowski et al demonstrated a device containing a PdAg film screen-printed from a commercial PdAg nanoparticulate ink and cured at high temperature for thermoelectric generation applications. ${ }^{170}$ Chiang investigated the antimicrobial efficacy of PdAg films, ${ }^{213}$ demonstrating that such alloys possess a similar activity to Ag. ${ }^{214}$ Choudhary demonstrated the use of sputtered PdAg 
films as part of a complex system for the direct preparation of $\mathrm{H}_{2} \mathrm{O}_{2}$ in high yield from the constituent elements. ${ }^{215}$

\subsection{State-of-the-Art Developments and Research}

A summary of the developments in the most recent literature (within the 12 months preceding publication) of PdAg films is presented. While the primary focuses of research remain as previously outlined: hydrogen-permeable membranes, ${ }^{216-220}$ and sensors.221 Advanced analytical methods have also been used to explore the properties and reactions of PdAg film. ${ }^{222,223} \mathrm{New}$ advancements in additive manufacturing technologies, such inkjet chemistries, could provide additional routes to $\mathrm{PdAg}$ films with appropriate engineering.224

Surface modifications of primary PdAg alloy hydrogen-permeable films with other metals and morphologies, such as $\mathrm{Zn},{ }^{216}$ and nanoporous surfaces respectively, ${ }^{217}$ have been demonstrated to improve hydrogen permittivity and lower effective temperatures and pressures, via reduction of ratelimiting reactions. ${ }^{216,217}$ Sequential heat-treatment methodologies have been investigated and proven to increase hydrogen permittivity for thinner $(<5 \mathrm{um})$ membranes. ${ }^{218}$ Advancements in preparative technologies have also been investigated, including high-powered magnetron sputtering-based PVD methods, ${ }^{219}$ and plasma methods..$^{220}$ Long-term studies investigating the performance of PdAg membranes over time have also been undertaken under varying reaction conditions, determining the maximum operational temperature of the materials for optimal longevity is $450{ }^{\circ} \mathrm{C} .{ }^{225}$

Spun-cast PdAg film sensors have been demonstrated as sensitive for the detection of E-coli bacteria in liquid media.221 The reaction of hydrogen with PdAg films has been mechanistically explored using state-of-the-art ambient-pressure XPS analysis, providing additional insight into permittivity processes, ${ }^{222}$ and computational simulations of such processes undertaken. ${ }^{223}$

\section{Conclusions}

In this review we have explored the manufacture and applications of the industrially important palladium silver alloy films. While the use of $\mathrm{PdAg}$ membranes for hydrogen purification has been known for many years and still represents the current research paradigm, further exploration of the capabilities of these materials in this and related applications have been undertaken. The most recent developments in the use of PdAg films are in highly selective sensing applications, primarily for the detection of $\mathrm{H}_{2}$, but also other low molecular weight species such as $\mathrm{CH}_{4}$. Electrocatalytic applications have also been explored, where the corrosion resistance and absorption behaviour of $\mathrm{PdAg}$ is suitable for use in fuel cells in particular.

Investigation of the preparative routes of PdAg membranes highlights opportunities beyond the conventional approaches used nowadays, namely additive manufacturing. While Pd and Ag films have been separately prepared using additive manufacturing routes, the preparation of $\mathrm{PdAg}$ films using this cutting edge technology has thus far remained elusive. Using an understanding of how $\mathrm{Pd}$ and $\mathrm{Ag}$ films can be prepared using AM, we have highlighted several potential routes to both PdAg thin films and porous structures. Additive manufacturing could allow for greater control and flexibility in the preparation of PdAg films for many applications, and of complex 3 dimensional morphologies of the same material for uses beyond those of membranes.

\section{Acknowledgements}

I wish to acknowledge the valued inputs of, and discussions with various members of the Additive Manufacturing group in the Department of Engineering at the University of Liverpool for their assistance in the preparation of this work.

\section{References}

1. M. Doriot-Werlé, O. Banakh, P.-A. Gay, J. Matthey and P.-A. Steinmann, Surf. Coat. Tech., 2006, 200, 66976701.

2. A. Faurschou, T. Menné, J. D. Johansen and J. P. Tyssen, Contact Dermatitis, 2011, 64, 185-195.

3. C. J. Goodacre, J. Prosthet. Dent., 1989, 62, 1, 34-37. 
4. K. Rebeiz et al., J. Energ. Eng., 2015, 141, 3, 04014029.

5. W. Grochala and P. P. Edwards, Chem. Rev., 2004, 104, 3, 1283-1316.

6. J. B. Hunter, Platinum Metals Rev., 1960, 4, 4, 130-131.

7. E. W. Pugh and F. M. Ryan, Phys. Rev., 1958, 111, 4, 1038-1042.

8. S. D. Axelrod and A. C. Makrides, J. Phys. Chem., 1964, 48, 8, 2154-2159.

9. A. S. Darling, Platinum Metals Rev., 1963, 7, 4, 126-129.

10. J. N. Pratt, Trans. Faraday Soc., 1960, 56, 957-987.

11. W. Sänger and J. Voitländer, Z. Physik B. Cond. Matt., 1981, 44, 4, 283-291.

12. M. Wang and Y. Feng, Sens. Act. B., 2007, 123, 101-106.

13. C. Y. Ho et al, J. Phys. Chem. Ref. Data, 1983, 12, 2, 183-322.

14. J. J. Conde, M. Maroon and J. M. Sanchez-Hervas, Separ. Purif. Rev., 2017, 46, 152-177.

15. R. C. Hughes, W. K. Schubert, T. E. Zipperian, J. L. Rodriguez and T. A. Plut, J. Appl. Phys., 1987, 62, 3, 10741083.

16. Z. Q. Ma, P. Cheng and T. S. Zhao, J. Membr. Sci., 2003, 215, 1-2, 327-336.

17. A. Iulianelli, P. K Seelam, S. Liguori, T. Longo, R. Keiski, V. Calabro and A. Basile, Int. J. Hydrog. Ener., 2011, 36, 6, 3827-3834.

18. J. Perelaer, R. Jani, M. Grouchko, A. Kamyshny, S. Magdassi and U. S. Schubert, Adv. Mater., 2012, 24, 39333998.

19. J. Perelaer, A. W. M. de Laat, C. E. Hendricks and U. S. Schubert, J. Mater. Chem., 2008, 18, 3209-3215.

20. E. G. Allison and G. C. Bond, Catal. Rev., 1972, 7, 2, 233-289.

21. L. W. McKeehan, Phys. Rev., 1922, 20, 424-432.

22. G. Zeng, A. Goldback and H. Xu, J. Membr. Sci., 2009, 326, 681-687.

23. A. Safavi, S. Momeni and M. Tohidi, Electroanal., 2012, 24, 10, 1981-1988.

24. A. K. Vijh and A. Belanger, Int. J. Hydrog. Ener., 1986, 11, 3, 147-151.

25. S. B. Walker and J. A. Lewis, J. Am. Chem. Soc., 2012, 134, 1419-1421.

26. K. Black, J. Singh, D. Mehta, S. Sung, C. J. Sutcliffe and P. R. Chalker, Sci. Rep., 2016, 6, 20814.

27. W. Sanger and J. Voitlander, Z. Phys. B., 1981, 44, 283-291.

28. J. A. Medrano, E. Fernandez, J. Melendez, M. Parco, D. A. P. Tanaka, M. v. S. Annaland and F. Gallucci, In. J. Hyrdog. Ener., 2016, 41, 8706-8718.

29. T. Graham, Proc. Royal Soc., 1868, 212-220.

30. F. D. Manchester, A. San-Martin and J. M. Pitre, J. Phase Equil., 1994, 15, 62.

31. E. L. Foletto, J. V. Wirbitzki da Silveira and S. L. Jahn, Lat. Amer. Appl. Res., 2008, 38, 79-84.

32. D. Mendes, A. Mendes, L. M. Madeira, A. Iulianelli, J. M. Sousa and A. Basile, Asia-Pac. J. Chem. Eng., 2010, 5, 111-137.

33. H. Kurokawa, K. Yakabe, I. Yasuda, T. Peters and R. Bredesen, Int. J. Hydrog. Ener., 2014, 39, 17201-17209.

34. A. Ramachandran, W. M. Tucho, A. L. Mejdell, M. Strange, H. J. Venvik, J. C. Walmsley, R. Holmestad, R. Bredesen and A. Borg, Appl. Surf. Sci., 2010, 256, 6121-6132.

35. T. A. Peters, T. Kaleta, M. Strange and R. Bredesen, J. Membr. Sci., 2013, 429, 448-458.

36. H.-T. Song, G.-M. Ma, J. Jiang, C.-R. Li, Y.-T. Luo and H.-B. Wang, Proc. 2015 EIC Conf., Seattle, Washington, USA, June 2015, 73-76.

37. T. Hubert, L. Boon-Brett and W. Buttner, Sensors for Safety and Process Control in Hydrogen Technologies, 2016, CRC Press, Florida, USA, Ch. 7.

38. S. Ghosh, C. RoyChaudhuri, R. Bhattacharya, H. Saha and N. Mukherjee, ACS Appl. Mater. Interf., 2014, 6, 3879-3887.

39. F. Bonet, S. Grugeon, R. Herrera Urbina, K. Tekaia-Elhsissen and J.-M. Tarascon, Solid State Sci., 2002, 5, 4, 665-670.

40. B. Heinrichs, J.-P. Schoebrechts and J.-P. Pirard, J. Catal., 2001, 200, 309-320.

41. I. Y. Ahn, J. H. Lee, S. K. Kim and S. H. Moon, Appl. Catal. A., 2009, 3601, 1, 38-42.

42. R. Dittmeyer, V. Hollein and K. Daub, J. Molec. Catal. A., 2001, 173, 135-184.

43. S. R. Chowdhury, P. S. Roy and S. K. Bhattacharya, Adv. Nat. Sci.: Nanosci. Nanotech., 2017, 8, 025002.

44. R. C. Sekol, X. Li, P. Cohen, G. Doubek, M. Carmo and A. D. Taylor, Appl. Catal. B., 2013, 138-139, $285-293$.

45. M. C. Oliveira, R. Rego, L. S. Fernandes and P. B. Tavares, J. Power Sourc., 2011, 196, 6092-6098.

46. F. Gauthard, F. Epron and J. Barbier, J. Catal., 2003, 220, 1, 182-191.

47. K. Esumi, R. Isono and T. Yoshimura, Langmuir, 2004, 20, 237-243.

48. F. Studt, F. Abild-Pedersen, T. Bligaard, R. Z. Sorensen, C. H. Christensen and J. K. Norskov, Angew. Chem., 2008, 120, 9439-9442.

49. E. A. Sales, J. Jove, M. d. J. Mendes and F. Bozon-Verduraz, J. Catal., 2000, 195, 88-95.

50. L. Chmielarz and M. Jablonska, RSC Adv., 2015, 5, 43408-43431. 
51. M. R. Rahimpour and A. Asgari, J. Haz. Mater., 2008, 153, 557-565.

52. P. Poizot, O. Durand-Drouhin, M. Lejeune and J. Simonet, Carbon, 2012, 50, 1, 73-83.

53. G.-T. Fu, C. Liu, Q. Zhang, Y. Chen and Y.-W. Tang, Sci. Rep., 2015, 5, 13703.

54. A. Bulut, M. Yurderi, Y. Karatas, Z. Say, H. Kivrak, M. Kaya, M. Gulcan, E. Ozensoy and M. Zahmakiran, ACS Catal., 2015, 5, 6099-6110.

55. J. B. Xu, T. S. Zhao and Z. X. Liang, J. Phys. Chem. C., 2008, 112, 17362-17367.

56. H. Kahri, M. Sevim and O. Metin, Nano Res., 2017, 10, 5, 1627-1640.

57. S. F. Wang, J. P. Dougherty, W. Huebner and J. G. Pepin, J. Am. Ceram. Soc., 1994, 77, 12, 3051-3072.

58. T. Maoka and M. Enyo, Electrochim. Acta., 1981, 26, 5, 607-614.

59. A. K. M. Fazle Kibria and Y. Sakamoto, Int. J. Hydrog. Ener., 2000, 25, 9, 853-859.

60. US. Pat. 3947333A, 1976.

61. A. Pozio, M. De Francesco, Z. Jovanovic and S. Tosti, Int. J. Hydrog. Ener., 2011, 36, 9, 5211-5217.

62. B. R. Coles, Proc. Phys. Soc. B, 1952, 62, 221-229.

63. G. C. Bond and A. F. Rawle, J. Molec. Catal. A: Chem., 1996, 109, 3, 261-271.

64. J. C. Taylor and B. R. Coles, Phys. Rev., 1956, 102, 1, 27-30.

65. X. Wang and G. Yushin, Energ. Enviro. Sci., 2015, 8, 1889-1904.

66. M. Yang and J. Dai, Photonic Sens., 2012, 2, 1, 14-28.

67. S. Saad, L. Hassine and W. Elfahem, Photonic Sens., 2014, 4, 3, 254-264.

68. Z. T. Geng, Q. He and Q. C. Jin, 2016 IOP Conf. Ser.: Mater. Sci. Eng., 2016, 137, 012009.

69. B. Sharma, H. M. Yadav and J.-S. Kim, IEEE Sens. Act. Sympos., 2017, Glassboro, USA.

70. J. Dai, M. Yang, X. Yu and H. Lu, Opt. Fiber Tech., 2013, 19, 26-30.

71. J. Hu, M. Jiang and Z. Lin, J. Optics A: Pure Appl. Optics., 2005, 7, 593-598.

72. G. M. Ma, J. Jiang, C. R. Li, H. T. Song, Y. T. Luo and H. B. Wang, Rev. Sci. Instru., 2015, 86, 045003.

73. L.-J. Cui, Y.-P. Chen and G. Zhang, Optoelec. Lett., 2009, 5, 3, 220-223.

74. W.-H. Lin, H.-F. Chang, Surf. Coat. Tech., 2005, 194-157-166.

75. E. Fernandez, A. Helmi, K. Coenen, J. Melendez, J. L. Viviente, D. A. P. Tanaka, M. v. S. Annaland and F. Gallucci, Int. J. Hydrog. Ener., 2015, 40, 3506-3519.

76. E. Fernandez, K. Coenen, A. Helmi, J. Melendez, J. Zuniga, D. A. P. Tanaka, M. v. S. Annaland and F. Gallucci, Int. J. Hydrog. Ener., 2015, 40, 13463-13478.

77. E. Fernandez, J. A. Medrano, J. Melendez, M. Parco, J. L. Viviente, M. v. S. Annaland, F. Gallucci and D. A. P. Tanaka, Chem. Eng. J., 2016, 305, 182-190.

78. E. Fernandez, J. A. Sanchez-Garcia, J. L. Viviente, M. v. S. Annaland, F. Gallucci and D. A. P. Tanaka, Molecules, 2016, 21, 210.

79. N. Vicinanza, I.-H. Svenum, L. N. Naess, T. A. Peters, R. Bredesen, A. Borg and H. J. Vinnik, J. Membr, Sci., $2015,476,602-608$.

80. T. Maneerung, K. Hidajat and S. Kawi, J. Membr. Sci., 2014, 452, 127-142.

81. Membrane Reactors for Hydrogen Production Processes, Eds. M. De Falco, L. Marrelli and G. Iaquaniello, 2011, Springer, London.

82. M. L. Bosko, J. F. Munera, E. A. Lombardo and L. M. Conaglia, J. Membr. Sci., 2010, 364, 17-26.

83. A. Basile and F. Gallucci, Membranes for Membrane Reactors: Preparation, Optimisation and Selection, 2011, Wiley, UK.

84. T. A. Peters, W. M. Tucho, A. Ramachandran, M. Strange, J. C. Walmsley, R. Holmestad, A. Borg and R, Bredesen, J. Membr. Sci., 2009, 326, 572-581.

85. T. A. Peters, M. Strange, M. F. Sunding and R. Bredesen, Int. J. Hydrog. Ener., 2015, 40, 3497-3505.

86. T. A. Peters, J. M. Polfus, M. Strange, P. Veenstra, A. Mijmeijer and R. Bredesen, Fuel Proc. Tech., 2015, 152, 259-265.

87. M. E. Ayturk and Y. H. Ma, J. Membr. Sci., 2009, 330, 233-245.

88. R. Bhandari and Y. H. Ma, J. Membr. Sci., 2009, 334, 50-63.

89. S. Uemiya, T. Endo, R. Yoshiie, W. Hatok and T. Kojima, Mater. Trans., 2007, 48, 5, 1119-1123.

90. K. Ghasemzadeh, S. Liguori, P. Morrone, A. Iulianelli, V. Piemonte, A. A. Bubaluo and A. Basile, Int. J. Hydrog. Ener., 2013, 38, 16685-16697.

91. A. Santucci, F. Borgognoni, M. Vadrucci and S. Tosti, J. Membr. Sci., 2013, 444, 378-383.

92. K. Zhang, S. K. Gade, O. Hatlevik and J. D. Way, Int. J. Hydrog. Ener., 2012, 37, 583-593.

93. B. P. Connor, G. P Manogharan, A. N. martof, L. M. Rodomsky, C. M. Rodomsky, D. C. Jordan and J. W. Limperos, Addit. Manufac., 2014, 1-4, 64-76.

94. K. F. Teng and R. W. Vest, IEEE Trans. Compon. Hybr. Manuf. Tech., 1987, CHMT-12, 4, 545-549.

95. K. F. Teng and R. W. Vest, IEEE Trans. Compon. Hybr. Manuf. Tech., 1988, 11, 3, 291-297.

96. D. I. Pethukov, M. N. Kirikova, A. A. Bessonov and M. J. A. Bailey, Mater. Lett., 2014, 132, 302-306. 
97. M. Mohl, A. Dombovari, R. Vajtai, P. M. Ajayan and K. Kordas, Sci. Rep., 2015, 5, 13710.

98. Z. Stempien, E. Rybicki, T. Rybicki and J. Lesnikowski, Sens. Act. B., 2016, 224, 714-725.

99. R. Zhang, W. Lin, K.-S. Moon and C. P. Wong, Appl. Mater. Interf., 2010, 2, 9, 2637-2645.

100. S. M. Bidoki, D. M. Lewis, M. Clark, A. Vakaraov, P. A. Millner and D. McGorman, J. Micromech. Microeng., 2007, 17, 967-947.

101. S. F. Jahn, T. Blaudeck, R. R. Baumann, A. Jakob, P. Ecorchard, T. Ruffer, H. Lang and P. Schmidt, Chem. Mater., 2010, 22, 3067-3071.

102. S. Magdassi, A. Bassa, Y. Vinetsky and A. Kamyshny, Chem. Mater., 2003, 15, 2208-2217.

103. Y. Tao, Y. Tao, B. Wang, L. Wang and Y. Tai, Nanoscale Res. Lett., 2013, 8, 296.

104. A. Sridhar, J. Reiding, H. Adelaar, F. Achterhoek, D. J. van Dijk and R. Akkerman, J. Micromech. Microeng., 2009, 19, 085020.

105. A. Kosmala, R. Wright, Q. Zhang and P. Kirby, Mater. Chem. Phys., 2011, 129, 1075-1080.

106. I. Reinhold, C. E. Hendricks, R. Eckardt, J. M Kranenburg, P. Perelaer, R. R. Baumann and U. S. Schubert, J. Mater. Chem., 2009, 19, 3384-3388.

107. M. Grouchko, A. Kamyshny and S. Magdassi, J. Mater. Chem., 2009, 19, 3057-3062.

108. S.-H. Lee, K.-Y. Shin, J. Y. Hwang, K. T. Tang and H. S. Kang, J. Micromech. Mincroeng, 2008, $18,075014$.

109. H.-H. Lee, K.-S. Chou and K.-C. Huang, Nanotech., 2005, 16, 2436-2441.

110. J. F. Salmeron, F. Molina-Lopez, D. Briand, J. J. Ruan, A. Rvadeneyra, M. A. Carvajal, L. F. Capitan-Vallvey, N. F. Derooij and A. J. Palma, J. Electr. Mater., 2014, 32, 2, 604-617.

111. F. Hoeng, J. Bras, E. Gicquel, G. Krosnicki and A. Denneulin, RSC Adv., 2017, 7, 15372-15381.

112. W. Shen, X. Zhang, Q. Huang, Q. Xu and W. Song, Nanoscale, 2014, 6, 1622-1628.

113. M. C. Dang, T. M. D. Dang and E. Fribourg-Blanc, Adv. Nat. Sci. Nanosci. Nanotech., 2015, 6, 015003.

114. J. Kastner, T. Faury, H. M. Ausserhuber, T. Obermuller, H. Liechtfried, M. J. Haslinger, E. Liftinger, J. Innerlohinger, I. Gnatiuk, D. Holzinger and T. Lederer, Microelec. Eng., 2017, 176, 84-88.

115. T. Bhuvana, W. Boley, B. Radha, B. D. Dolash, G. chiu, D. Bergstrom, R. Reifenberger, T. S. Fisher and G. U Kulkarni, Micro Nano Lett., 2010, 5, 5, 296-299.

116. W. Boley, T. Bhuvana, B. Hines, R. A. Sayer, G. Chiu, T. S. Fisher, D. Bergstrom, R. Reifenberger and G. U Kulkarni, NIP25 and Digital Fabrication 2009, Proc. Soc. Imag. Sci. Tech., 2009, 824-827.

117. Y. Qin, A. U. Alam, M. M. R. Howlander, N.-X. Hu and M. J. Deen, Adv. Funct. Mater., 2016, 26, 4923-4933.

118. Y. Qin, A. U. Alam, M. M. R. Howlander, N.-X. Hu and M. K. Deen, J. Mater. Chem. C., 2017, 5, 1893-1902.

119. S. Busato, A. Belloli and P. Ermanni, Sens. Act. B., 2007, 123, 840-846.

120. J. C. Bailar (Ed.), Comprehensive Inorganic Chemistry, Pergamon, Oxford, UK, 1973.

121. A. M. Tarditi, M. L. Bosko and L. M. Cornaglia, Int. J. Hydrog. Ener., 2012, 37, 6020-6029.

122. S.-Y. Lu and Y.-Z. Lin, Thin Solid Films, 2000, 376, 67-72.

123. M. Kariniemi, J. Niinisto, T. Hatanpaa, M. Kemell, T. Sajavaara, M. Ritala and M. Leskela, Chem. Mater., 2011, 23, 2901-2907.

124. J. Hamalainen, M. Ritala and M. Leskela, Chem. Mater., 2014, 26, 786-801.

125. J. W. Elam, A. Zinovev, C. Y. Han, H. H. Wang, U. Welp, J. N. Hryn and M. J. Pellin, Thin Solid Films, 2006, 515, 1664-1673.

126. Z. Y. Li, H. Maeda, K. Kusakabe, S. Morooka, h. Anzai and S. Akiyama, J. Membr. Sci., 1993, 78, $245-254$.

127. T. Bhatia, A. Ozturk, L. Xie, E. H. Jordan, B. M. Cetegen, M. Gell, X. Ma and N. P. Padture, J. Mater. Res., $2002,17,9,2363-2372$.

128. T. Jurzinsky, C. Cremers, K. Pinkwart and J. Tubke, Electrochim. Acta, 2016, 199, $270-279$.

129. K. R. Patil, Y. K. Hwang, M.-J. Kim, J.-S. Chang and S.-E. Park, J. Coll. Interf. Sci., 2004, 276, 333-338.

130. J. H. Son, D. H. Lee, Y. J. Cho and M. H. Lee, J. Nansci. Nanotech., 2012, 12, 7, 5827-5829.

131. P. J. Shaver, Rev. Sci. Instru., 1969, 40, 901-905.

132. J. Koike, D. M. Parkin and M. Nastasi, J. Mater. Res., 1990, 5, 7, 1414-1418.

133. M. Paunovic in Modern Electroplating, Eds.: M. Schlesinger and M. Paunovic, 2011, Wiley, UK.

134. Electroless Plating: Fundamentals and Applications, Eds: G. O. Mallory and J. B. Hajdu, 1990, Noyes, New York, USA.

135. B. A. McCool and Y. S. Lin, J. Mater. Sci., 2001, 36, 3221-3227.

136. N. Selvakumar and H. C. Barshilia, Solar Energ. Mater. Solar Cells, 2012, 98, 1-23.

137. P. Echlin, C. E. Fiori, J. Goldstein, D. C. Joy and D. E. Newbury, Advanced Scanning Electron Microscopy and X-Ray Analysis, 1986, Springer, New York.

138. R. E. I. Schropp, B. Stannowski, A. M. Brockhoff, P. A. T. T. van Veenendaal and J. K. Rath, Mater. Phys. Mech. I, 2000, 73-82.

139. K. Assim, M. Melzer, M. Korb, T. Ruffer, A. Jakob, J. Noll, C. Georgi, S. E. Schulz and H. Lang, RSC Adv., 2016, 6, 102557-102569. 
140. N. L. Jeon, W. Lin, M. K. Erhardt, G. S. Girolami and R. G. Nuzzo, Langmuir, 1997, 13, 3833-3838.

141. R. W. Johnson, A. Hultqvist and S. F. Bent, Mater. Today, 2014, 17, 5, 236-246.

142. F. Piskin, H. Akyilidz and T. Ozturk, Int. J. Hydrog. Ener., 2015, 40, 7553-7558.

143. J. B. Mooney and S. B. Radding, Ann. Rev. Mater. Sci., 1982, 12, 81-101.

144. K. Nagashima, T. Himeda and A. Kato, J. Mater. Sci., 1991, 26, 2477-2482.

145. T. C. Pluym, T. T. Kodas, L.-M. Wang and H. D. Glicksman, J. Mater. Res., 1995, 10, 7, 1661-1673.

146. Y.-G. Jo, S.-M. Kim and S.-Y. Lee, Jap. J. Appl. Phys., 2016, 55, 01AE01

147. T. Teranishi and M. Miyake, Chem. Mater., 1998, 10, 594-600.

148. J. A. Darr, J. Zhang, N. M. Makwana and X. Weng, Chem. Rev., 2017, 117, 11125-11238.

149. Y. Cao, R. Zheng, X. Ji, H. Liu, R. Xie and W. Yang, Langmuir, 2014, 30, 3876-3882.

150. R. N. Cassar, D. Graham, I. Larmour, A. W. Wark and K. Faulds, Vibrat. Spec., 2014, 71, 41-46.

151. Z. Huang, J. Jiang, P. Liu, J. Sun, D. Guo, J. Shan and N. Gu, J. Mater. Chem. A, 2015, 3, 1925-1929.

152. S. M. Landage, A. I. Wasif and P. Dhuppe, Int. J. Adv. Res. Eng. Appl. Sci., 2014, 3, 5, 14-22.

153. H. Ma, B. Yin, S. Wang, Y. Jiao, W. Pan, S. Huang, S. Chen and F. Meng, Chem. Phys. Chem., 2004, 5, 68-75.

154. O. S. Oluwafemi, Y. Lucwaba, A. Gura, M. Masabeya, V. Ncapayi, O. O. Olujimi and S. P. Songca, Coll. Surf. B: Biointerf., 2013, 10, 718-723.

155. J. Tharion, J. Satija and S. Mukherji, Plasmonics, 2015, 10, 753-763.

156. W. Zhang, X. Qiao and J. Chen, Mater. Sci. Eng. B., 2007, 142, 1-15.

157. B. G. Ershov, E. V. Abkhalimov and A. V. Anan'ev, Doklady Phys. Chem., 2011, 439, 2, 142-144.

158. D. Gupta, P. B. Barman and S. K. Hazra, AIP Conf. Proc., 2016, 1728, 020542.

159. K. Kakaei and M. Dorraji, Electrochim. Acta, 2014, 143, 207-215.

160. S. Peiris, S. Sarina, C. Han, Q. Xiao and H.-Y. Zhu, Dalton Trans., 2017, 46, 10665-10672.

161. K. Tedsree, T. Li, S. Jones, C. W. A. Chan, K. M. K. Yu, P. A. J. Bagot, E. A. Marquis, G. D. W. Smith and S. C. E. Tsang, Nature Nanotech., 2011, 6, 302-307.

162. A. Moisala, A. G. Nasibulin and E. I Kauppinen, J. Phys: Cond, Mater., 2003, 15, 3011-3035.

163. R. Mueller, L. Madler and S. E. Pratsinis, Chem. Eng. Sci., 2003, 58, 10, 1969-1976.

164. W. F. Chu, L. H. Erdmann and M. Ilgenstein, Sens. Act. B., 1991, 4, 321-324.

165. US Pat. 5011627A, 1991.

166. US Pat. 4187340 A, 1980.

167. US Pat. 4425263, 1984.

168. US Pat. $4858364,1987$.

169. F. Menil, C. Lucat, H. Debeda, Sens. Act. B., 1995, 24-25, 415-420.

170. P. Markowski and A. Dziedzic, Microelec. Reliab., 2008, 48, 890-896.

171. S. Hoff, Screen Printing - A contemporary Approach, 1997, Delmar, New York, USA.

172. D. E. Bornside, C. W. Macasko and L. E. Scriven, J. Imag. Tech., 1987, 13, 4, 122-130.

173. J. Burschka, N, Pellet, S.-J. Moon, R. Humphry-Baker, P. Gao, M. K. Nazeeruddin and M. Gratzel, Nature, 2013, 499, 316-319.

174. J. N. Cawse, D. Olson, B. J. Chisholm, M. Brennan, T. Sun, W. Flanagan, J. Akhave, A. Mehrabi and D. Saunders, Prog. Organ. Coat., 2003, 47, 2, 128-135.

175. M. Tejos, R. Schrebler, F. Diaz and M. A. del Valle, Bol. Soc. Chil. Quim., 2002, 47, 2, 113-121.

176. S. Schaefers, L. Rast and A. Stanishevsky, Mater. Lett., 2006, 60, 706-709.

177. M. Taufik and P. K. Jain, J. Manufac. Sci. Eng., 2016, 138, 6, MANU-15-1125.

178. N. T. Aboulkhair, N. M. Everitt, I. Ashcroft and C. Tuck, Additive Manufac., 2014, 1-4, 77-86.

179. N. Sclater and N. P. Chironis, Mechanisms and Mechanical Devices Sourcebook, 2001, McGraw-Hill, New York, USA.

180. J.-P. Kruth, M. C. Leu and T. Nakagawa, CIRP Annals, 47, 2, 1998, 525-540.

181. C. Peng, W. Yang, E. Wu, W. Ma, X. Zheng, Y. Nie, H. Zhang and J. Xu, J. Alloys Compounds, 2017, 698, 250258.

182. W. Hong, J. Wang and E. Wang, Electrochem. Comm., 2014, 40, 63-66.

183. L.-X. Chen, J.-N. Zheng, A.-J. Wang, L.-J. Wu, J.-R. Chen and J.-J. Feng, Analyst, 2015, 140, 3183-3192.

184. A. L. Dearden, P. J. Smith, D.-Y. Shin, N. Reis, B. Derby and P. O'Brien, Macromol. Rap. Comms., 2005, 26, 315-318.

185. M. Aminuzzaman, A. Watanbe and T. Miyashita, Thin Sol. Films, 2009, 517, 5935-5939.

186. A. Kamyshny, M. Ben-Moshe, S. Aviezer and S. Magdassi, Macromol. Rap. Comms., 2005, 26, 281-288.

187. L. K. Jong, J. B. Ho, K. T. Hoon and J. Jaewoo, Nanotech., 2006, 17, 2424.

188. J. R. Vargas Carcia and T. Goto, Mater. Trans., 2003, 44, 9, 1717-1728.

189. M. Vazquez, Magnetic Nano- and Microwires, Woodhead, 2015, Ch. 2, p81.

190. T. Reda, C. M. Plugge, N. J. Abram and J. Hirst, Proc. Nat. Acad. Sci., 105, 31, 10654-10658. 
191. M. Kumar in Carbon Nanotubes - Synthesis, Characterisation and Applications, Ed. S. Yellampalli, Intech, London.

192. A. B. Venediktov, S. V. Korenev, S. P. Khranenko, S. V. Tkachev, P. E. Plyusnin, S. N. Mamonov, L. V. Ivanova and V. A. Vostrikov, Russ. J. Appl. Chem., 2007, 80, 5, 695-704.

193. A. I. Pereira, P. Perez, A. Mendes, L. M. Madeira and C. J. Tavares, $12^{\text {th }}$ Int. Conf. Catal. Membr. React., 2013, Porto, Portugal.

194. A. I. Pereira, P. Perez, S. C. Rodrigues, A. Mendes, L. M. Madeira and C. J. Tavares, Mater. Res. Bull., 2015, 61, 528-533.

195. A. F. Vyatkin, V. T. Volkov, V. G. Eremenko, Y. A. Kasumov and A. S. Kolchina, J. Surf. Invest. X-Ray, Synch. Neutr. Tech., 2015, 9, 3, 558-563.

196. J. Shu, B. P. A. Grandjean and S. Kaliaguine, Appl. Cat. A.: Gen., 1994, 119, 305-325.

197. J. Shu, A. Adnot, B. P. A. Grandjean and S. Kaliaguine, Thin Sol. Films, 1996, 286, 72-79.

198. E. Kikuchi, Catal. Today, 1995, 25, 333-337.

199. J. N. Keuler, L. Lorenzen and S. Miachon, Separ. Sci. Tec., 2002, 37, 2, 379-401.

200. J. N. Keuler and L. Lorenzen, J. Membr. Sci., 2002, 202, 17-26.

201. M. Vadrucci, F. Borgognoni, A. Moriani, A. Santucci and S. Tosti, Int. J. Hydrog. Ener., 2013, 38, 4144-4152.

202. J. Catalano, F. Guazzone, I. P. Mardilovich, N. K. Kazantzis and Y. H. Ma, Ind. Eng. Chem. Res., 2013, 52, 1042-1055.

203. J. Catalano, M. G. Baschetti and G. C. Sarti, Int. J. Hydrog. Ener., 2011, 36, 8658-8673.

204. Y. W. Budhi, I. Noezar, F. Aldiansyah, P. V. Kemala, A. A. B. padama, H. Kasai and Subagjo, Int. J. Hydrog. Ener., 2011, 36, 15372-15381.

205. A. Brunetti, G. Barbieri and E. Drioli, Chem. Eng. Sci., 2009, 64, 3448-3454.

206. W. M. Tucho, H. J. Venvik, M. Strange. J. C. Walmsley, R. Holmestad and R. Bredesen, Separ. Purif. Tech., 2009, 68, 403-410.

207. T. H. Nguyen, S. Mori and M. Suzuki, Chem. Eng. J., 2009, 155, 55-61.

208. A. P. Kryshtal, S. I. Bogatyrenko, R. V. Sukhov and A. A. Milenkov, Appl. Phys. A., 2014. 116, 1891-1896.

209. S. Yan, H. Maeda, K. Kusakabe and S. Morooka, Ind. Eng. Chem. Res., 1994, 33, 616-622.

210. A. L. Mejdell, D. Chen, T. A. Peters, R. Bredesen and H. J. Venvik, J. Membr. Sci., 2010, 350, 371-377.

211. A. J. Mejdell, M. Jondahl, T. A. Peters, R. Bredesen and H. J. Venvik, Separ. Purif. Tech., 2009, 68, 178-184.

212. P. Bhattacharyya, P. K. Basu, H. Saha and S. Basu, Sens. Act. B., 2007, 214, 62-67.

213. W.-C. Chiang, PhD Thesis, Technical University of Denmark, 2009.

214. M. Y. Vaidya, M. J. McBain, J. A. Butler, C. E. Banks and K. A. Whitehead, Sci. Rep., 2017, 7, 5911.

215. V. R. Choudhary, A. G. Gaikwad and S. D. Sansare, Angew. Chem. Int. Ed.,2001, 40, 9, 1776-1779.

216. I. S. Petriev, S. N. Bololtin, V. Y. Frolov, M. G. Baryshev, and V. A. Sozayev, Bull. Russ. Acad. Sci.: Phys., 2018, 82, 7, 807-810.

217. I. S. Petriev, J. Phys: Conf. Ser., 2018, 1134, 012045.

218. N. Vicinanza, I.-H. Svenum, T. Peters, R. Bredesen, and H. Venvik, Membranes, 2018, 8, 92.

219. S. Barison et al, Int. J. Hydrog. Ener., 43, 16, 7982-7989.

220. A. Wunsch et al, Membranes, 2018, 8, 4, 107.

221. N. M. Naim, H. Abdullah, and A. A. Hamid, Elect. Mater. Lett., 2019, 15, 1, 70-79.

222. J. Tang et al, Appl. Surf. Sci., 2019, 463, 1161-1167.

223. I. S. Petriev et al, Russ. Phys. J., 2019, 61, 10, 1894-1898.

224. Y. Sui et al, Adv. Mater. Tech., 2019, 1900119.

225. N. De Nooijer et al, Processes, 2019, 7, 2, 106. 